\title{
Oil charging history and pathways of the Ordovician carbonate reservoir in the Tuoputai region, Tarim Basin, NW China
}

\author{
Rong-Hui Fang ${ }^{1}$ Mei-Jun $\mathrm{Li}^{1} \cdot$ Hai-Tao Lü̈ ${ }^{2}$ T. -G. Wang ${ }^{1}$ Yuan Yuan ${ }^{1,3}$ • \\ Yong-Li Liu ${ }^{2} \cdot$ Zhi-Yong Ni ${ }^{1}$
}

Received: 27 March 2017/Published online: 3 November 2017

(C) The Author(s) 2017. This article is an open access publication the Awati and Manjiaer Depressions. Traps located in the southern side of the Tuoputai region, along the oil charging pathways, should therefore be preferred oil exploration targets.

Keywords Oil population · Oil charging events · Fluid inclusion - 1D numerical modeling · Oil filling pathway

\section{Introduction}

The Tuoputai region is located in the Tabei Uplift of the Tarim Basin, NW China. It is situated on the southwest slope of the Akekule High (Fig. 1), which has been affected by multiple tectonic events (Zhang 1999; Zhou et al. 2001; $\mathrm{Li}$ and $\mathrm{Xu}$ 2004). In terms of petroleum yield, the Tuoputai region is one of the most prolific blocks in the Tahe Oilfield, which is the largest oilfield of marine origin in China, with over $3.2 \times 10^{8} \mathrm{t}$ proven in-place oil/gas reserves (Wang et al. 2008). Up to now, more than 100 wells delivering moderate to high commercial yields have been drilled in the Tuoputai region. The majority of oil accumulations occur in the Ordovician carbonate reservoir.

The source of the Ordovician oil reservoir in the Tabei Uplift of the Tarim Basin has long been a controversial issue, because the oils are of high thermal maturity and there are few wells of sufficient depth to penetrate the potential source rock intervals ( $\mathrm{Li}$ et al. 2010a, b; Chang et al. 2013a). However, more and more studies have indicated that oils in the Tabei Uplift are sourced from MiddleUpper Ordovician carbonate source rocks (Zhang et al. 2000; Zhang and Huang 2005; Wang et al. 2008; Yu et al. 2011; Chang et al. 2013a).

Edited by Jie Hao 


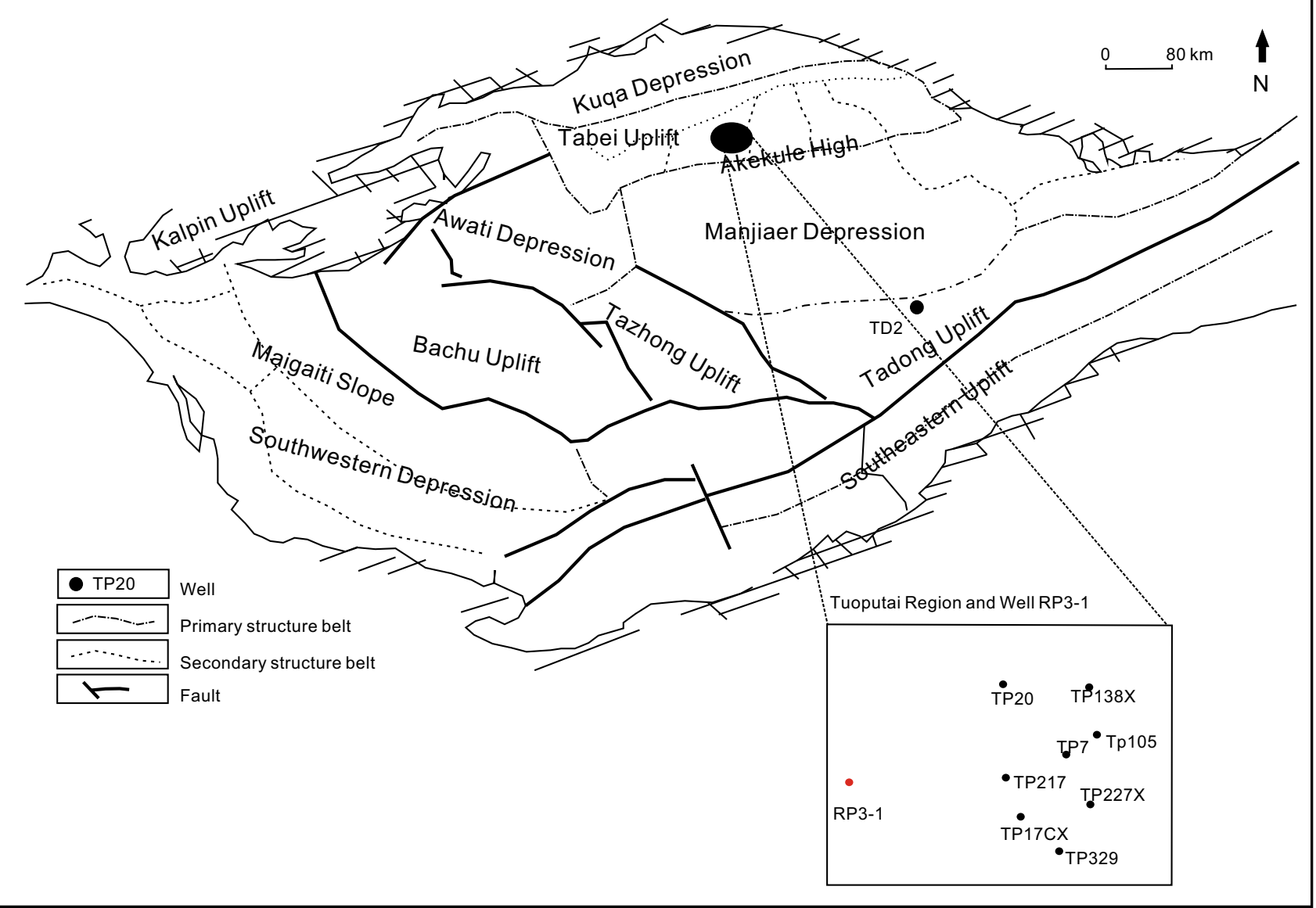

Fig. 1 Map showing well locations in the Tuoputai region of the Tabei Uplift of the Tarim Basin, NW China

Previous reports (Gu 2000; Ding et al. 2001) have proposed that the Tahe Oilfield has experienced multistage oil charging events, from the Carboniferous-Permian to Mesozoic-Neogene periods, based on the saturation/bubble point pressure of crude oil pools, homogenization temperatures $\left(T_{\mathrm{h}}\right)$ of fluid inclusions and reservoir bitumen reflectance. Chen et al. (2003) proposed that five oil charging events, ranging from the Middle Carboniferous to Neogene, may have occurred in the Tahe Oilfield on the basis of the fluorescent colors of fluid inclusions. Based on the $T_{\mathrm{h}}$ of fluid inclusions and reconstructed burial and geothermal histories, Wang et al. (2008) proposed that the Tahe Ordovician oil reservoir has been charged twice. The early oil charging phase arose from the Middle to Late Silurian (429-415 Ma) and the later one from the Miocene to Pliocene (8-2 Ma). Shi et al. (2012) reported that the Ordovician reservoirs in the Tuoputai region have been charged twice, and the early oil charge occurred from 420 to $405 \mathrm{Ma}$ and the second from 8 to $2 \mathrm{Ma}$ based on the integrated analyses of microthermometry, petrography, laser Raman spectrum and confocal laser scanning microscopy of fluid inclusions. Ni et al. (2016) and Xiao et al. (2016) reported that there were two phases of oil charging in the Halahatang Depression, west of the Tuoputai region, the first phase was from the Middle to Late Silurian (422-410 Ma), and the second occurred during the middle Miocene (20-6 Ma).

Recently, more and more work has been done on the oil filling history and oil charging pathways of the Ordovician carbonate reservoirs in the Tabei Uplift. Using tricyclic terpanes/17 $\alpha(\mathrm{H})$-hopanes ratios of 18 oil samples from the Tahe Oilfield, Huang (2003) traced oil migration orientations. The results showed that the general orientation of oil charging is from east to west and from south to north, suggesting that the source kitchen may be located in the Manjiaer Depression (Huang 2003). By combining multiple molecular indicators, such as the total content of pyrrolic nitrogen compounds and 4-/1-MDBT, Wang et al. (2004a, 2008) determined that oils charge from south to north generally in the Tahe Oilfield. Much work has also been done, using various geochemical parameters, on the oil filling history and migration orientation of Ordovician reservoirs in other oilfields in the Tabei Uplift, including the Lunnan Oilfield (Wang et al. 2004b; Zhang and Huang 2005; Gong et al. 2007; Lu et al. 2008; Zhu et al. 2013), the Yakela Oilfield (Li et al. 2013a, b) and the Halahatang 
Oilfield (e.g., Chang et al. 2013b; Fang et al. 2016; Xiao et al. 2016). However, little work has been done on the oil reservoir geochemistry of the Tuoputai region in the Tabei Uplift.

This study investigated oil filling pathways from systematic geochemical analyses of 62 crude oil samples from 62 different wells in the Tuoputai region of the Tabei Uplift. By combining the homogenization temperatures of fluid inclusions with reconstructed burial and geothermal histories, episodes of oil filling in the Ordovician reservoir and their timing were also identified and determined. The results of this study will further help to predict the location of the source beds/kitchen and identify preferred exploration targets in the Tabei Uplift.

\section{Geological settings and samples}

The Tuoputai region of the Tabei Uplift is surrounded by the Caohu Depression to the east, the Halahatang Depression to the west, the Manjiaer Depression to the south and the Hadexun Structure Belt to the southeast (Fig. 1). The Tabei Uplift has undergone multistage tectonic events, including (1) the formation of the pre-Sinian basement and rift during the Sinian to Ordovician, (2) the formation of a paleo-uplift during the Silurian to Permian and its evolution (250-290 Ma), (3) the formation of a foreland basin during the Triassic to Jurassic period, (4) the extension of the basin during the Cretaceous to Neogene and (5) the rapid subsidence from the late Neogene to Quaternary (Kang and Kang 1996; Jia and Wei 2002; Jin et al. 2008; Zhu et al. 2011, 2013; Fang et al. 2016). The sedimentary successions of the Tabei Uplift are marine sediments (Sinian to Ordovician), marine-terrestrial transitional successions (Carboniferous to Permian) and terrestrial sequences (Triassic to Quaternary). The main Ordovician reservoirs in the Tuoputai region occur in the LowerMiddle Ordovician Yingshan $\left(\mathrm{O}_{1-2} y\right)$, the Middle Ordovician Yijianfang $\left(\mathrm{O}_{2} y\right)$ and the Upper Ordovician Lianglitage $\left(\mathrm{O}_{3} l\right)$ Formations, mainly composed of bioclastic limestones, calcarenite, micrite and dolomite.

In this study, 62 oil samples were gathered from the Tuoputai region. Two typical oil samples collected from Wells TD2 and T904 were also analyzed for comparison. Oils in these two wells are considered to be sourced from Cambrian-Lower Ordovician source rocks (Ma et al. 2005; Zhang and Huang 2005; Li et al. 2010a, b, 2012, 2015; Song et al. 2016).

\section{Methods}

\subsection{Sample preparation}

The crude oil samples were analyzed as follows: asphaltenes were precipitated using $n$-hexane and then isolated by filtration. Then, the resulting $n$-hexane solutions were separated into saturated and aromatic hydrocarbon fractions by silica gel/alumina $(3: 2, \mathrm{w} / \mathrm{w})$ column chromatography, using $n$-hexane and dichloromethane/ $n$-hexane $(2: 1 \mathrm{v} / \mathrm{v})$ as eluents, respectively.

\subsection{Gas chromatography-mass spectrometry (GC- MS) analyses}

The GC-MS analyses of the saturated and aromatic hydrocarbon fractions were conducted on an Agilent 6890 gas chromatograph, equipped with an HP-5MS (5\% phenylmethylpolysiloxane) fused silica capillary column (60 $\mathrm{m} \times 0.25 \mathrm{~mm}$ i.d., with a $0.25 \mu \mathrm{m}$ film thickness). The chromatograph was coupled to an Agilent 5975i mass spectrometry system, which operated at $70 \mathrm{eV}$ within a mass range of 50-600 Da. Helium was used as the carrier gas. For the saturated fractions, the GC operating conditions were as follows: the oven temperature was set at $50{ }^{\circ} \mathrm{C}$ initially for $1 \mathrm{~min}$, ramped to $120^{\circ} \mathrm{C}$ at $20^{\circ} \mathrm{C} / \mathrm{min}$, subsequently to $310^{\circ} \mathrm{C}$ at $3{ }^{\circ} \mathrm{C} / \mathrm{min}$ and finally held isothermally for $25 \mathrm{~min}$. For the aromatic fractions, the oven temperature was set at $80^{\circ} \mathrm{C}$ for $1 \mathrm{~min}$, then ramped to $310{ }^{\circ} \mathrm{C}$ at $3{ }^{\circ} \mathrm{C} / \mathrm{min}$ and finally held isothermally for $16 \mathrm{~min}$. The split injector temperature was set at $300^{\circ} \mathrm{C}$.

\subsection{Microthermometry of fluid inclusions}

A total of 10 carbonate cores were sampled from the production interval of the Middle Ordovician Formation $\left(\mathrm{O}_{2} y\right)$ in Well TP37.

Analyses of fluid inclusions were performed as follows: Double-polished thin sections were prepared for fluid inclusion observation, and the homogenization temperatures measured using a Linkam Model THMSG 600 heating-cooling stage coupled to a Leica Model DMRXP optical microscope. The measurement range was between -196 and $600{ }^{\circ} \mathrm{C}$, and the freezing and heating error was, respectively \pm 0.1 and $\pm 2{ }^{\circ} \mathrm{C}$. After adjustment of temperature, measurements were set at a rate of $15{ }^{\circ} \mathrm{C} / \mathrm{min}$ and then the rate gradually decreased to 5 and $2{ }^{\circ} \mathrm{C} / \mathrm{min}$. Finally, the rate was decreased to $1{ }^{\circ} \mathrm{C} / \mathrm{min}$ when the fluid inclusion was close to homogenization. 


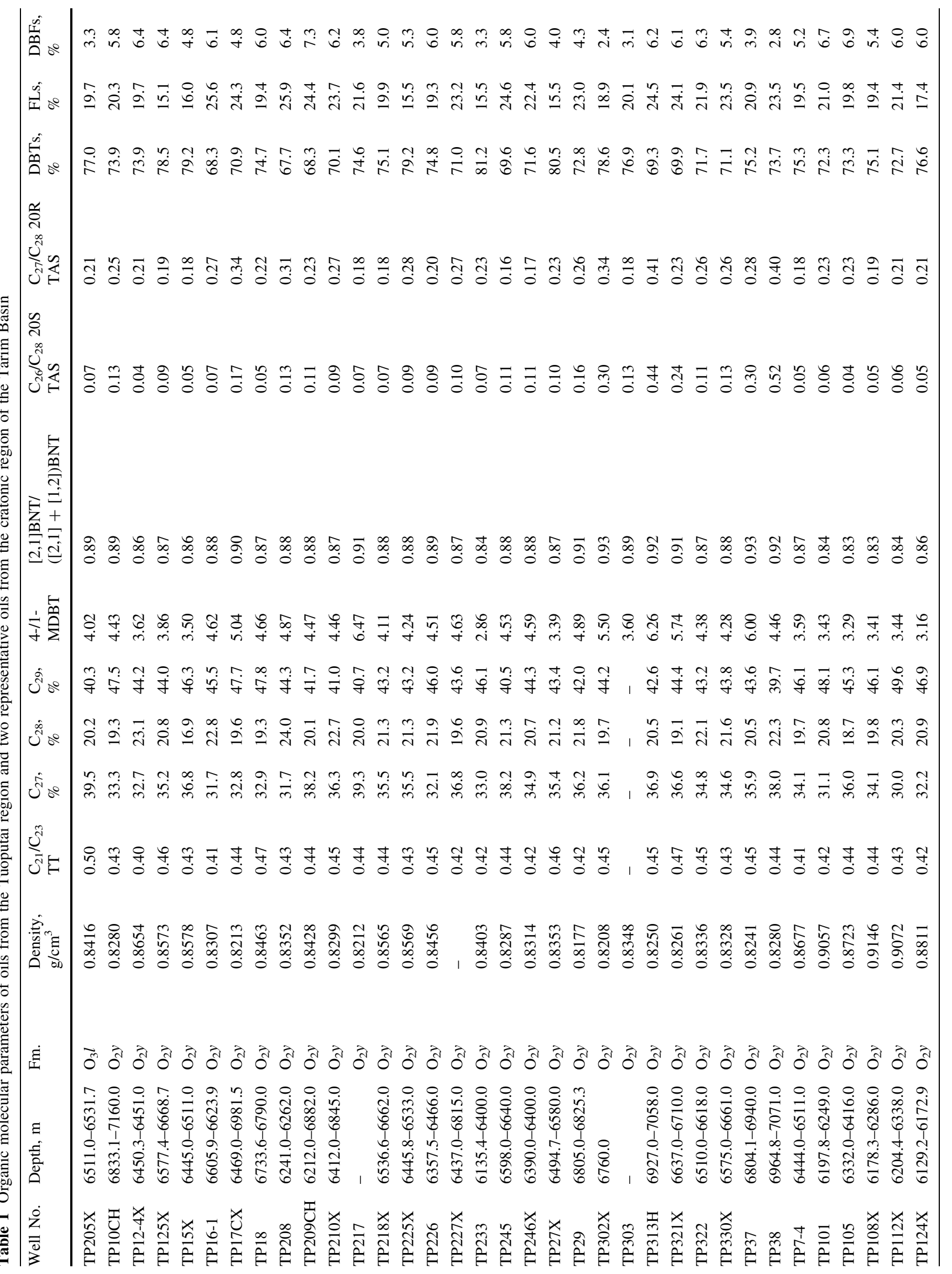




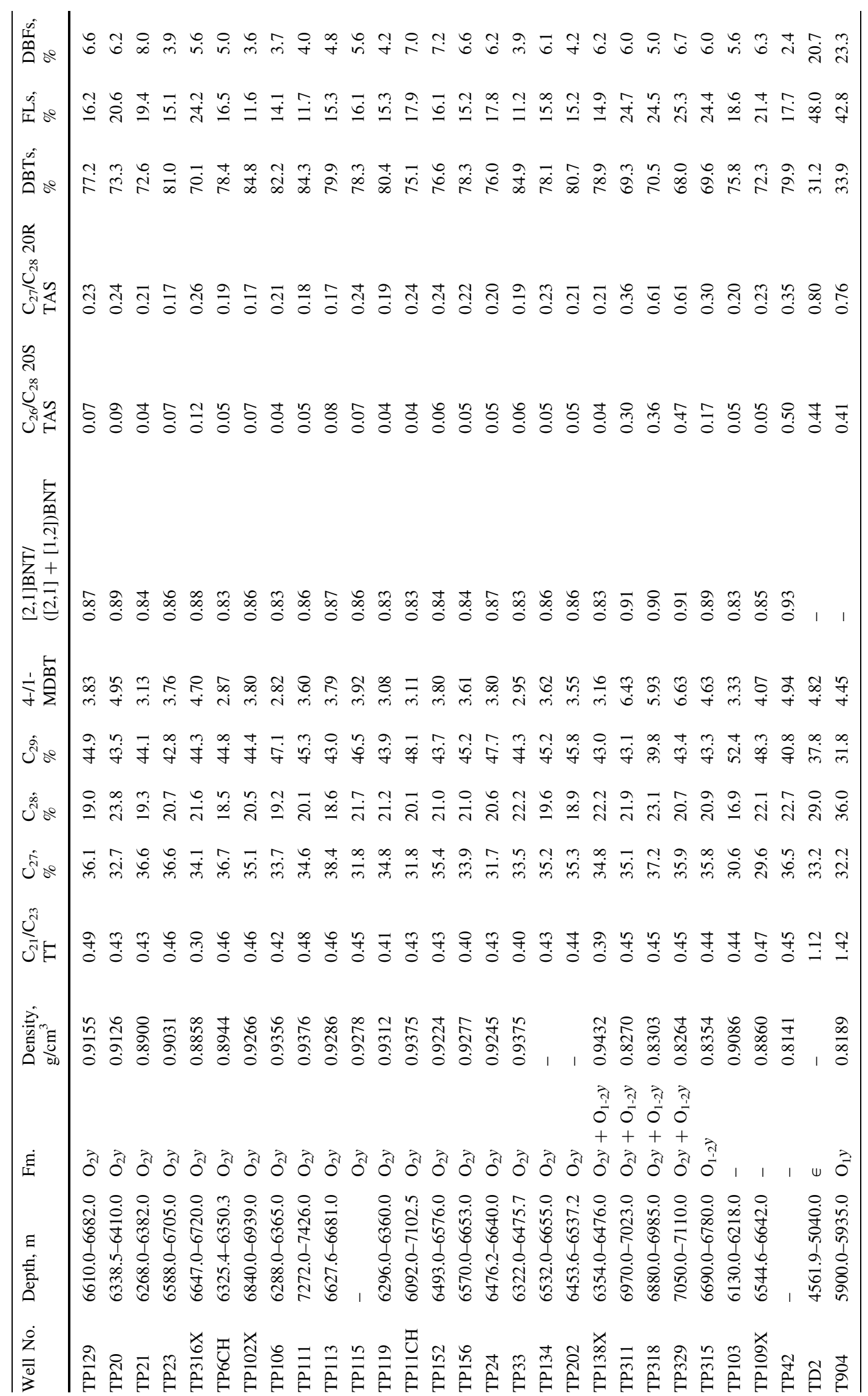


$m / z 217$
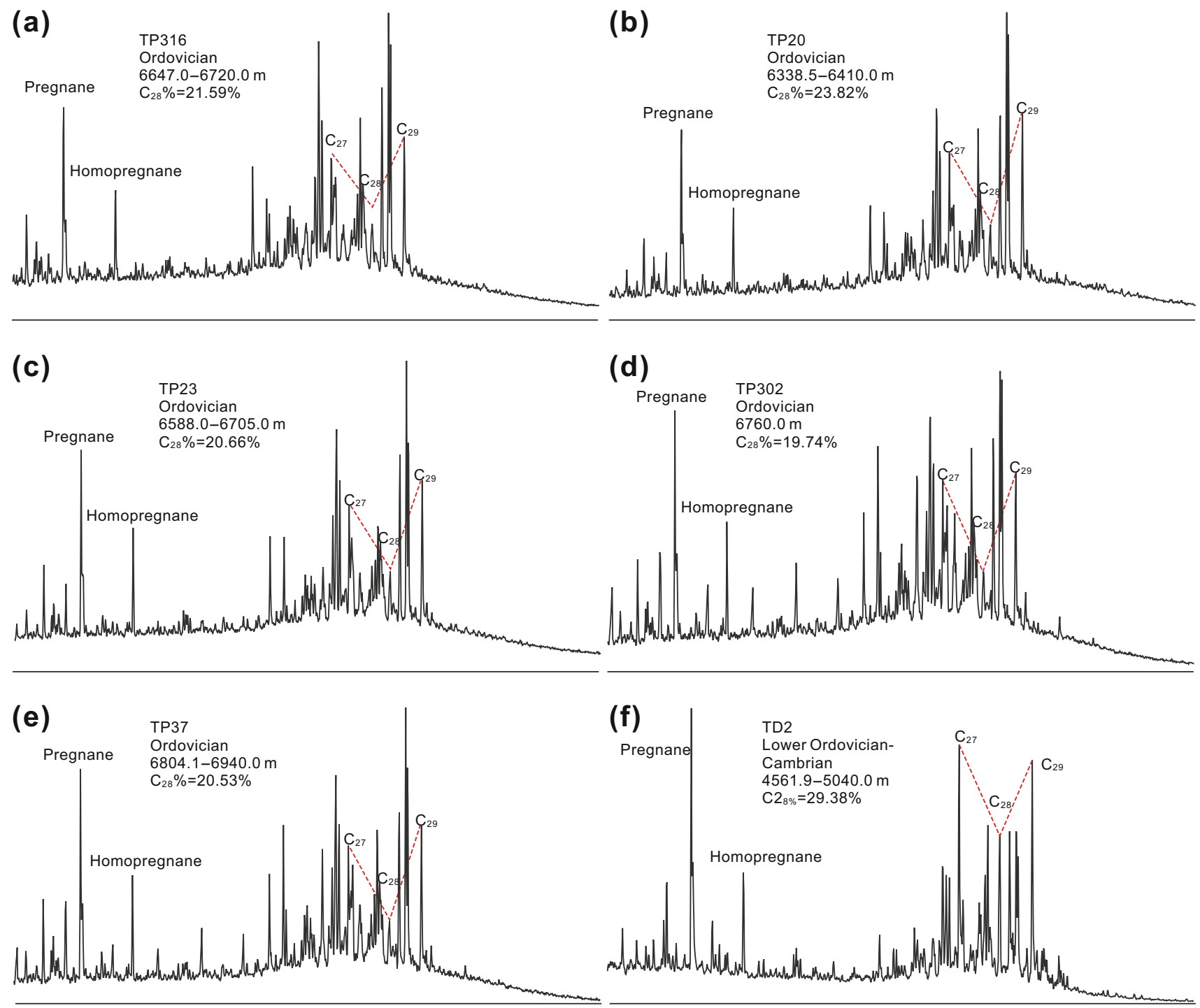

Relative retention time

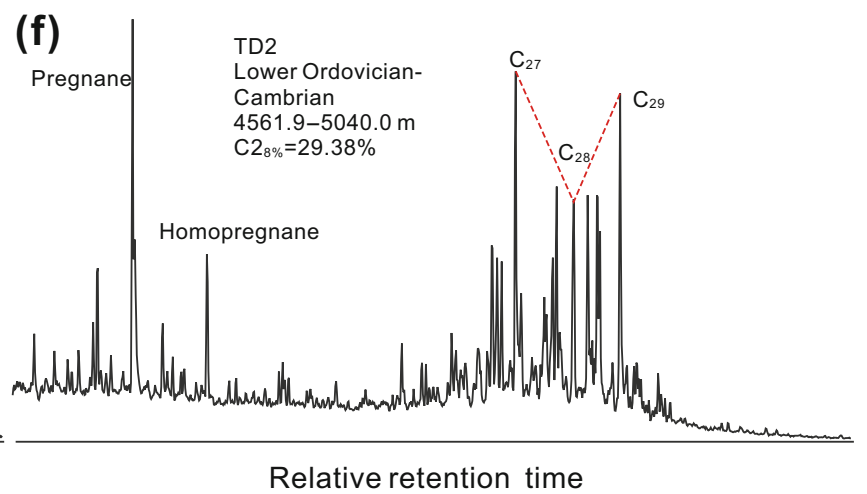

Fig. 2 Mass chromatograms $(\mathrm{m} / \mathrm{z}, 217)$ showing the distribution patterns of steranes in selected oils of the Tuoputai region and Well TD2 from the Tarim Basin

\section{Results and discussion}

\subsection{Composition and population of Ordovician oil in the Tuoputai region}

Sixty-four oil samples (including two oils from wells in the cratonic region of the Tarim Basin) (Table 1) were analyzed geochemically to study their organic molecular composition and classify their oil population. Various molecular indicators relative to tricyclic terpanes, hopanes, $\mathrm{C}_{27}-\mathrm{C}_{29}$ regular steranes, triaromatic steroids and selected polycyclic aromatic compounds were applied in this study.

Figure 2 maps $\mathrm{m} / \mathrm{z} 217$ mass chromatograms of the saturates in the oils show the distribution pattern of steranes. All oils in the Tuoputai region are characterized by a "V-shape" distribution pattern (Fig. 2) of the relative abundances of $\mathrm{C}_{27}-\mathrm{C}_{28}-\mathrm{C}_{29}$ regular steranes. The relative content of $\mathrm{C}_{28}$ regular steranes in all Tuoputai oils is lower than $25 \%$ (Table 1), which is consistent with data from the Middle-Upper Ordovician source rocks (Hanson et al. 2000; Zhang et al. 2000; Zhang and Huang 2005; Li et al. 2012). A ternary diagram based on the relative molecular compositions of $\mathrm{C}_{27}-\mathrm{C}_{28}-\mathrm{C}_{29}$ regular steranes (Fig. 3a) is a method commonly used to determine oil-to-oil correlation and oil classification (Peters et al. 2005). Here we found that all the oils from the Tuoputai region have a similar composition of $\mathrm{C}_{27}, \mathrm{C}_{28}$ and $\mathrm{C}_{29}$ regular steranes and are closely distributed in one group (Fig. 3a). A ternary 

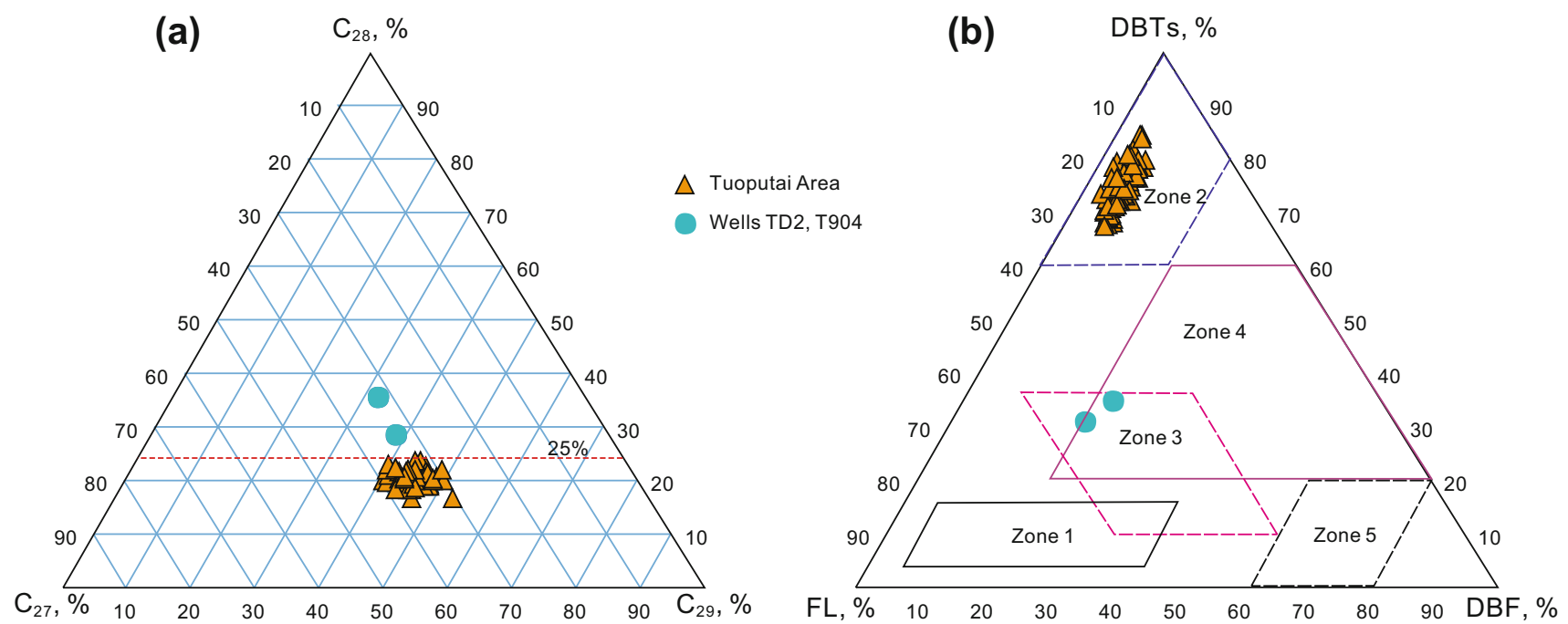

Fig. 3 Ternary diagrams showing proportions of $\mathrm{C}_{27}, \mathrm{C}_{28}, \mathrm{C}_{29}$ regular steranes, $\mathbf{b}$ fluorenes (FLs), dibenzothiophenes (DBTs) and dibenzofurans (DBFs) in the Ordovician oil pools of the Tuoputai region from the Tarim Basin, NW China. In b, Zone 1: fluvial/deltaic/fresh water lacustrine shale; Zone 2: marine carbonate; Zone 3: marine shale; Zone 4: brackish/saline lacustrine shale; Zone 5: swamp. After Li et al. (2013a, b)

diagram mapping the relative abundance of dibenzothiophenes (DBTs), fluorenes (FLs) and dibenzofurans (DBFs) can be used effectively to investigate depositional environments, oil-to-oil and oil-to-source correlation ( $\mathrm{Li}$ et al. 2013a, b). All oils from the Tuoputai region have a relatively high content of DBTs, with the ratio of DBTs/ (DBTs + FLs + DBFs) higher than 70\% (Fig. 3b). This indicates a strongly reducing depositional environment and their source from marine carbonates ( $\mathrm{Li}$ et al. 2013a, b).

Figure 4 shows the distribution of tricyclic terpanes (TTs) and hopanes in $\mathrm{m} / \mathrm{z} 191$ mass chromatographs of saturates from selected oil samples. The content of tricyclic terpanes (TTs) is relatively higher than hopanes in all Tuoputai oils, and the relative content of $\mathrm{C}_{23} \mathrm{TT}$ is higher than that of $\mathrm{C}_{21} \mathrm{TT}$ with a $\mathrm{C}_{21} \mathrm{TT} / \mathrm{C}_{23} \mathrm{TT}$ ratio lower than 1.0 , which is consistent with the majority of oils from other oilfields in the Tabei Uplift (Wang et al. 2008; Chang et al. 2013a; Xiao et al. 2016).

Triaromatic steroids (TAS) are relatively abundant in the studied region (Fig. 5). Previous studies have been reported that most oils originating from Middle-Upper Ordovician source rocks have relatively low abundances of $\mathrm{C}_{26}, \mathrm{C}_{27}$ TAS $\left(\mathrm{C}_{26} 20 \mathrm{~S}, \mathrm{C}_{26} 20 \mathrm{R}+\mathrm{C}_{27} 20 \mathrm{~S}, \mathrm{C}_{27} 20 \mathrm{R}\right)$ and a high content of $\mathrm{C}_{28}$ TAS, while oils from CambrianLower Ordovician source rocks feature higher concentrations of $\mathrm{C}_{26}, \mathrm{C}_{27}$ TAS relative to $\mathrm{C}_{28}$ TAS (Zhang et al. 2002; Mi et al. 2007; Li et al. 2012; Xiao et al. 2016). Figure 5 shows that the Ordovician oils in the studied region have relatively low contents of $\mathrm{C}_{26}, \mathrm{C}_{27}$ TAS and a high content of $\mathrm{C}_{28}$ TAS, with a ratio of $\mathrm{C}_{26} / \mathrm{C}_{28} 20 \mathrm{~S}$ TAS $<0.50$ and $\mathrm{C}_{27} / \mathrm{C}_{28} \quad$ 20R $\quad$ TAS $<0.60$ (Fig. 5, Table 1). All of these molecular markers clearly show that oils in the Ordovician carbonate reservoir of the Tuoputai region have similar molecular compositions, as well as a high degree of consistency in source affinity and oil accumulation history. They clearly belong to a single oil family and may all derive from Middle-Upper Ordovician source rocks/beds.

However, oils from Wells TD2 and T904 are significantly different from the Ordovician oils in molecular composition. The TD2 and T904 oils have a relatively high abundance of $\mathrm{C}_{28}$ regular steranes $(>25 \%)$ (Figs. 2, 3a, Table 1), a lower abundance of DBTs (Fig. 3b, Table 1), higher $\mathrm{C}_{21} \mathrm{TT}$ content $\left(\mathrm{C}_{21} / \mathrm{C}_{23} \mathrm{TT}>1.0\right)$ (Fig. 4 , Table 1$)$, and higher $\mathrm{C}_{26}$ and $\mathrm{C}_{27}$ TAS contents $\left(\mathrm{C}_{26} / \mathrm{C}_{28} \quad 20 \mathrm{~S}\right.$ TAS $>0.4, \mathrm{C}_{27} / \mathrm{C}_{28}$ 20R TAS $>0.75$ ) (Fig. 5, Table 1), indicating that they derived from a different oil family. Previous reports showed that oils in these wells derived from Cambrian-Lower Ordovician source rocks (e.g., Li et al. 2010a, b, 2012, 2015; Song et al. 2016).

\subsection{Oil charging history and timing of entrapment}

From the microthermometric characteristics of fluid inclusions in the carbonate reservoir rock samples from Well TP37, it can be deduced that there were two phases of fluid inclusion formation. Aqueous inclusions paragenetic with the hydrocarbon inclusions were observed, and their homogenization temperatures $\left(T_{\mathrm{h}}\right)$ were measured. There are distinctive differences between the two phases of fluid inclusion in $T_{\mathrm{h}}$ and ice final melting temperatures. A total of 107 data points of $T_{\mathrm{h}}$ were measured. A histogram of $T_{\mathrm{h}}$ values of aqueous inclusions displays a bimodal distribution pattern, with the majority of the first phase within 


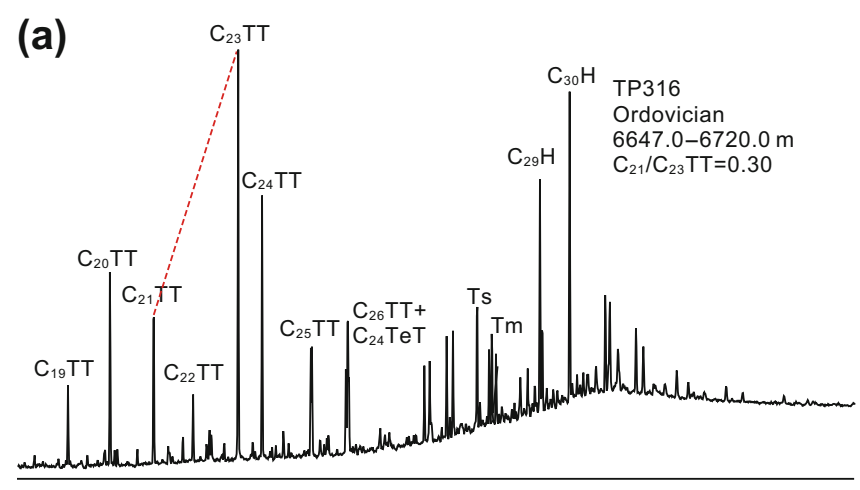

$\mathrm{m} / \mathrm{z} 191$
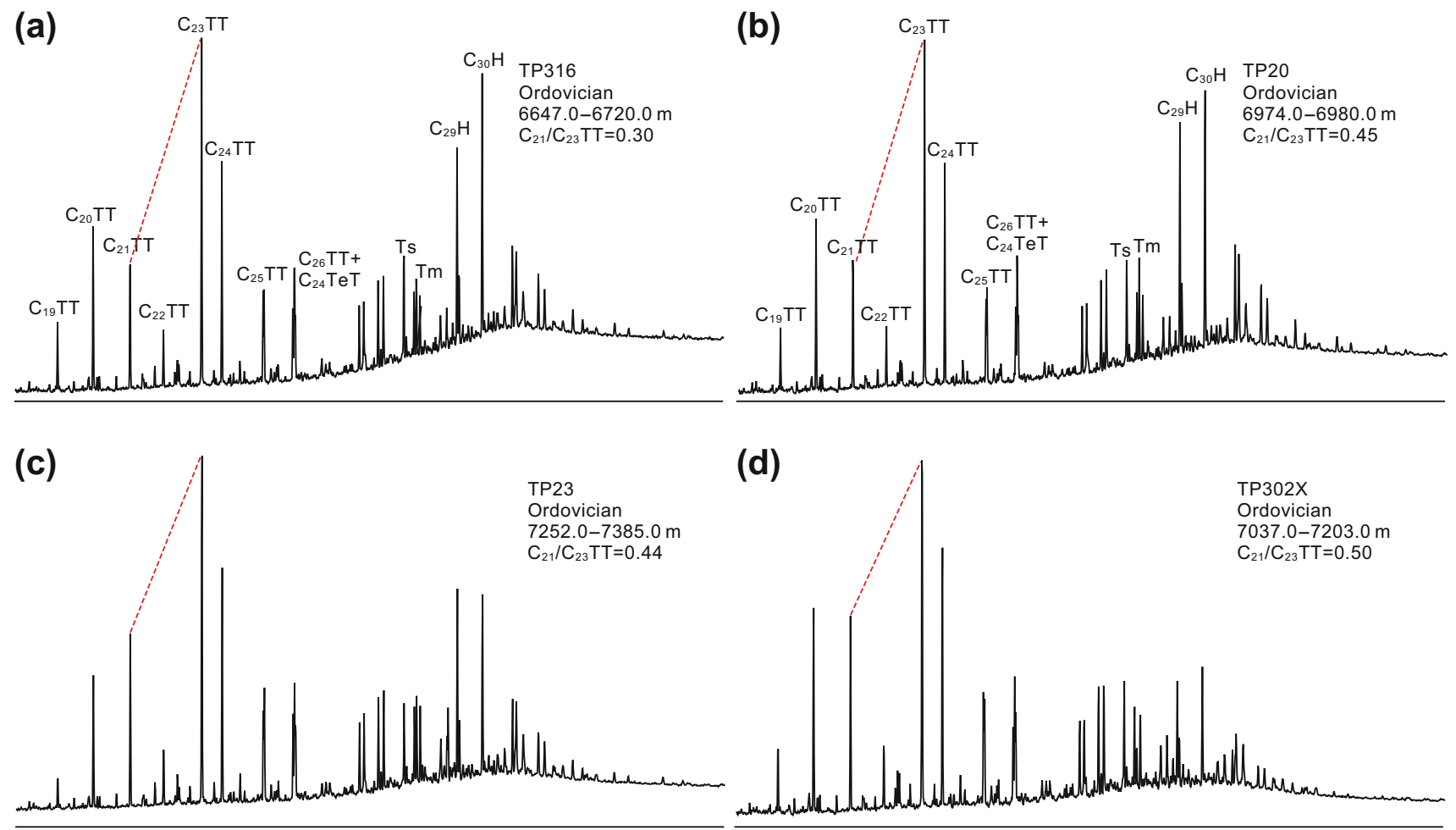

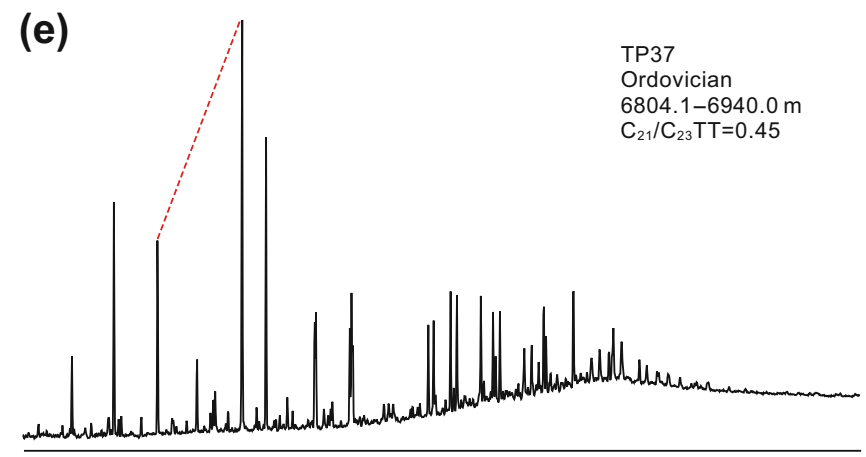

Relative retention time

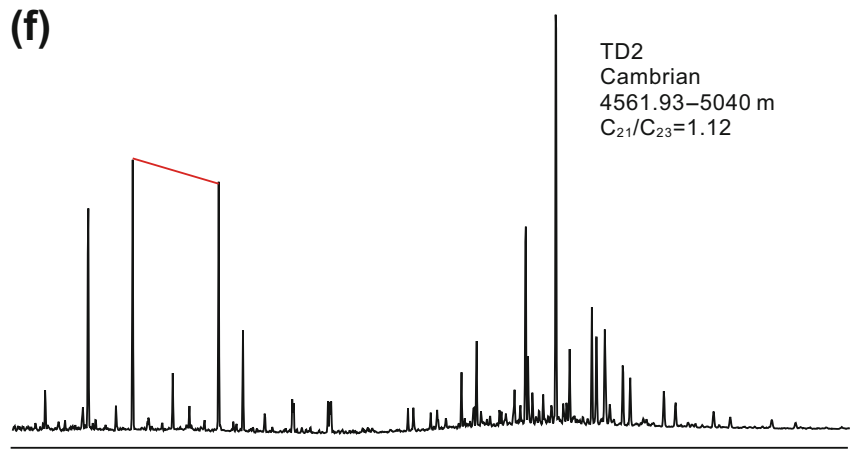

Relative retention time

Fig. 4 Mass chromatograms $(\mathrm{m} / \mathrm{z}, 191)$ showing the distribution patterns of tricyclic terpanes and hopanes in selected oils of the Tuoputai region and Well TD2 from the Tarim Basin

$80-90{ }^{\circ} \mathrm{C}$ and the second within $110-120{ }^{\circ} \mathrm{C}$ (Fig. 6), suggesting different fluid inclusion entrapment temperatures for these two oil charging events. In addition, the ice final melting temperature values range from -11.0 to $-10{ }^{\circ} \mathrm{C}$ for the first phase and from -7 to $-6{ }^{\circ} \mathrm{C}$ for the second, indicating obvious differences in diagenetic paleofluid properties between the two fluid inclusion phases. The water should be more saline in the fluid inclusion of the first phase than in that of the second.

Homogenization temperatures and pressures are the minimum-trapping temperatures and pressures of fluid inclusions. They should be calibrated by using PVT simulation modeling (Liu et al. 2003, 2005). As well, the ratios of vapor/liquid in petroleum-bearing fluid inclusions were obtained accurately using confocal laser scanning microscopy (CLSM) (Ni et al. 2016). The Tuoputai region and the adjacent Halahatang Sag have undergone the same tectonic events and have similar thermal histories, so we choose samples from Well RP3-1 of the Halahatang Sag for the PVT simulation modeling (Ni et al. 2016). Based on isochors of a number of petroleum inclusions in Well RP31 in the Halahatang Oilfield of the Tabei Uplift (Ni et al. 2016; Xiao et al. 2016), the trapping temperatures of the first and the second phases of fluid inclusions in typical Ordovician carbonate reservoirs range from 82 to 97 and 136 to $170{ }^{\circ} \mathrm{C}$, respectively. The calibration of aqueous 
$m / z 231$

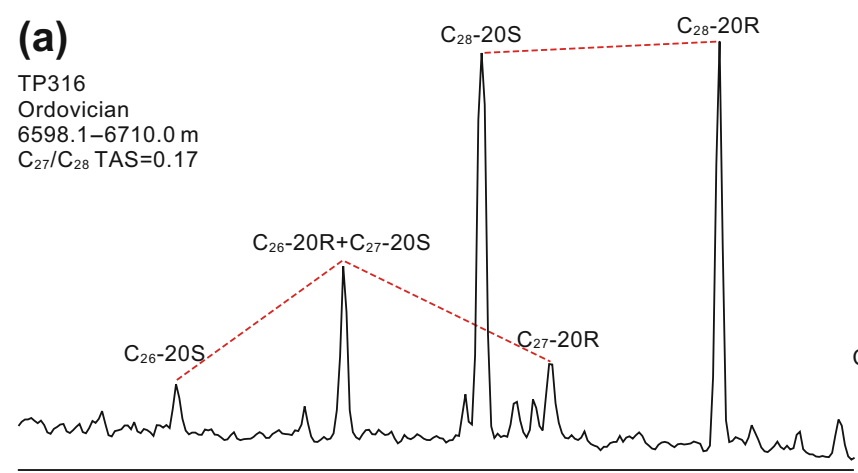

(b)

TP20

Ordovician

6974.0-6980.0 m

$\mathrm{C}_{27} / \mathrm{C}_{28} \mathrm{TAS}=0.21$

\section{(c)}

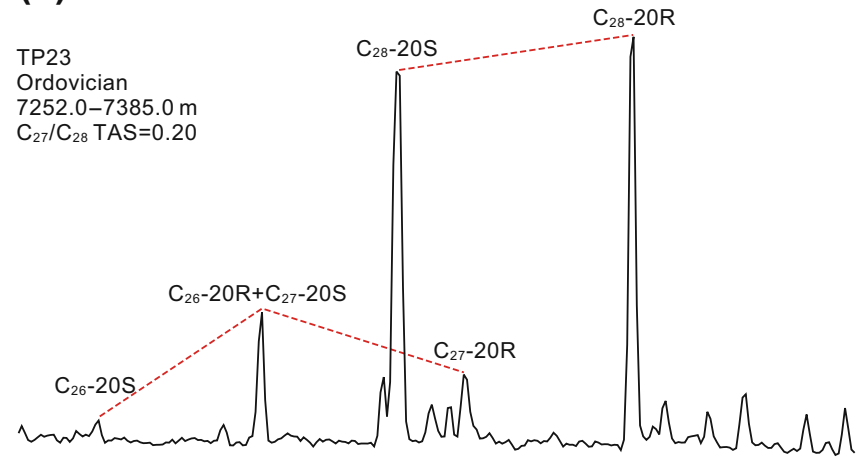

(d)

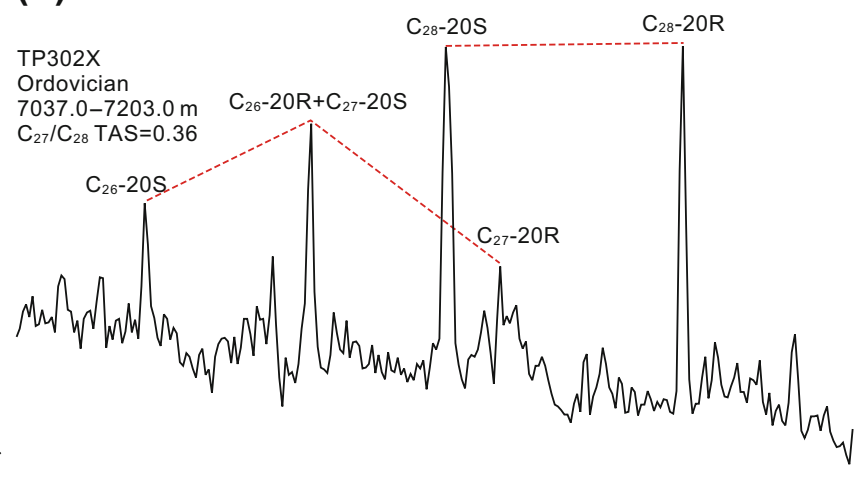

\section{(e)}

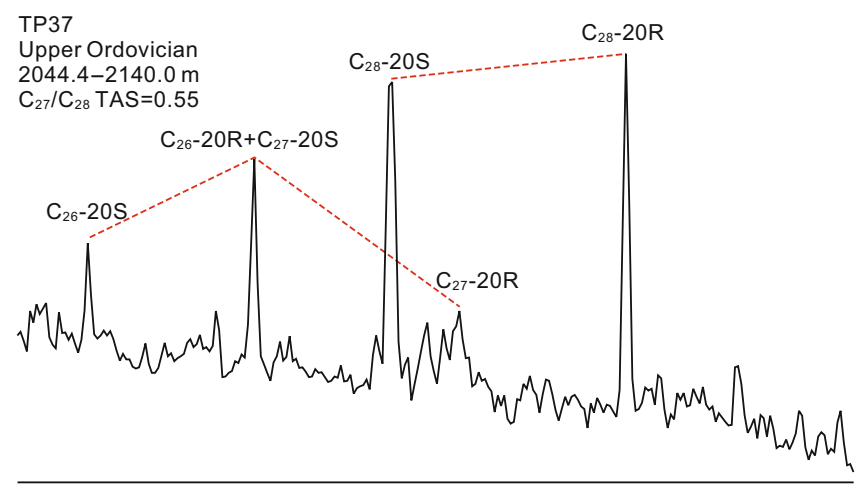

Relative retention time (f)

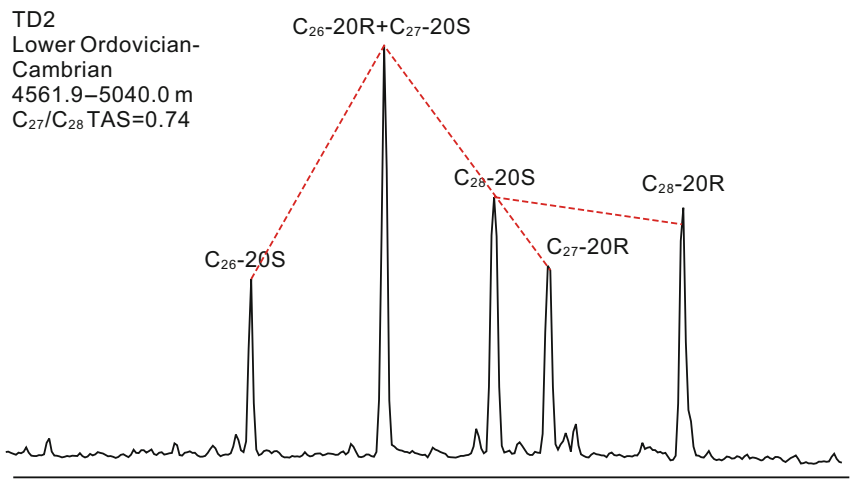

Relative retention time

Fig. 5 Mass chromatograms $(\mathrm{m} / \mathrm{z}, 231)$ showing the distribution patterns of triaromatic steroids in selected oils of the Tuoputai region and Well TD2 from the Tarim Basin

inclusions temperatures is $\approx 10{ }^{\circ} \mathrm{C}$ higher than the measured $T_{\mathrm{h}}$ for the first phase and $\approx 40{ }^{\circ} \mathrm{C}$ for the second phase (Xiao et al. 2016). Therefore, the trapping temperatures of fluid inclusions in the Ordovician oil reservoirs of Well TP37 range from 90 to 100 , and 150 to $160{ }^{\circ} \mathrm{C}$, respectively.

Stratigraphic burial and thermal histories for Well TP37 (Fig. 7) were reconstructed using one-dimensional (1D) numerical modeling (Fig. 7). The geological parameters input into the software and the method used were determined by reference to $\mathrm{Li}$ et al. (2010a, b). A maturity profile based on the measured vitrinite reflectance $\left(R_{\mathrm{o}} \%\right)$ was established (Fig. 8). Optimization processes have been conducted until the calculated values matched with the measured one ( $\mathrm{Li}$ et al. 2010a, b). Here we found that the calculated maturity profile is consistent overall with that measured (Fig. 8). Therefore, the modeled stratigraphic burial and thermal histories are reliable and practical. Combined with the reconstructed stratigraphic burial and thermal histories, entrapment temperatures can be related 


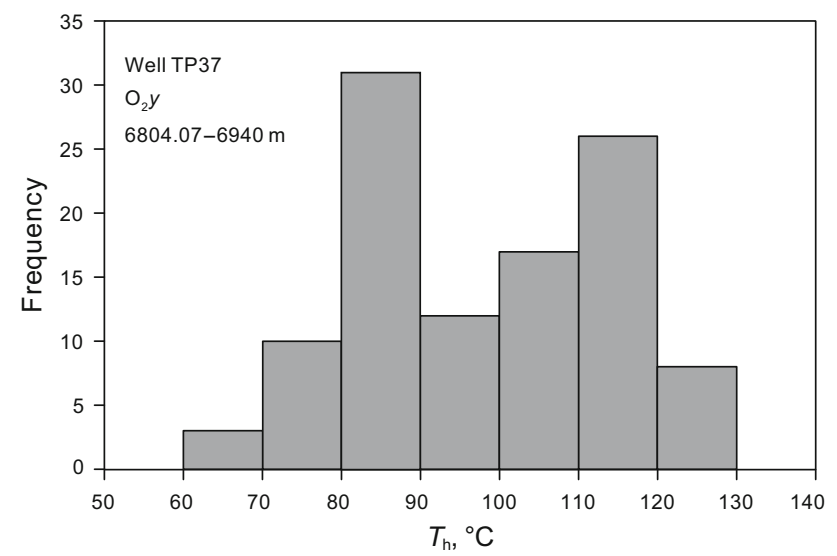

Fig. 6 Histogram of homogenization temperatures $\left(T_{\mathrm{h}}\right)$ of fluid inclusions in the Ordovician carbonate reservoir in Well TP37

to geological ages for the oil charging events in the Ordovician reservoir of the Tuoputai region (Fig. 7).

Figure 7 shows that the Ordovician reservoir in Well TP37 has been charged twice from 425 to 412 and 9 to $4 \mathrm{Ma}$, respectively. The history and timing of oil charging in the Tuoputai Ordovician reservoir are generally consistent with those of the wells in the major part of the Tahe Oilfield (Wang et al. 2008).

\subsection{Oil charging orientation and filling pathways}

It has been reported that the relative content of alkyldibenzothiophene isomers (4-/1-MDBT and 2,4-/1,4DMDBT) can be applied as a molecular tracer for oil migration pathways (Wang et al. 2004a, 2008). These molecular indicators were successfully applied in Tertiary sandstone reservoirs in the north margin basins of the South China Sea (Wang et al. 2004a; Li et al. 2008) and in the Ordovician carbonate reservoir of a karst pore-fissurenetwork type in the Tahe and Halahatang Oilfields of the Tarim Basin (Wang et al. 2004a, 2008; Li et al. 2014a, b; Fang et al. 2016). The results suggest that these parameters can be used as an effective tracing indicator for oil filling orientation and migration pathways.

Bressler et al. (1997) and Mazeas et al. (2002) have reported that methylated dibenzothiophene may be susceptible to biodegradation, especially the $\mathrm{C}_{1}$ and $\mathrm{C}_{2}$ alkyldibenzothiophene. Recently, Shi et al. (2015) reported the absolute content of DBTs and BNTs decrease with increasing biodegradation degree; however, the relative content of alkyl DBTs with same number of methyl groups and BNTs has no significant change according to a preliminary experiment. Therefore, 4-/1-MDBT and $[2,1] \mathrm{BNT} /([2,1] \mathrm{BNT}+[1,2] \mathrm{BNT})$ are primarily influenced by the oil filling fractionation (Fang et al. 2016).

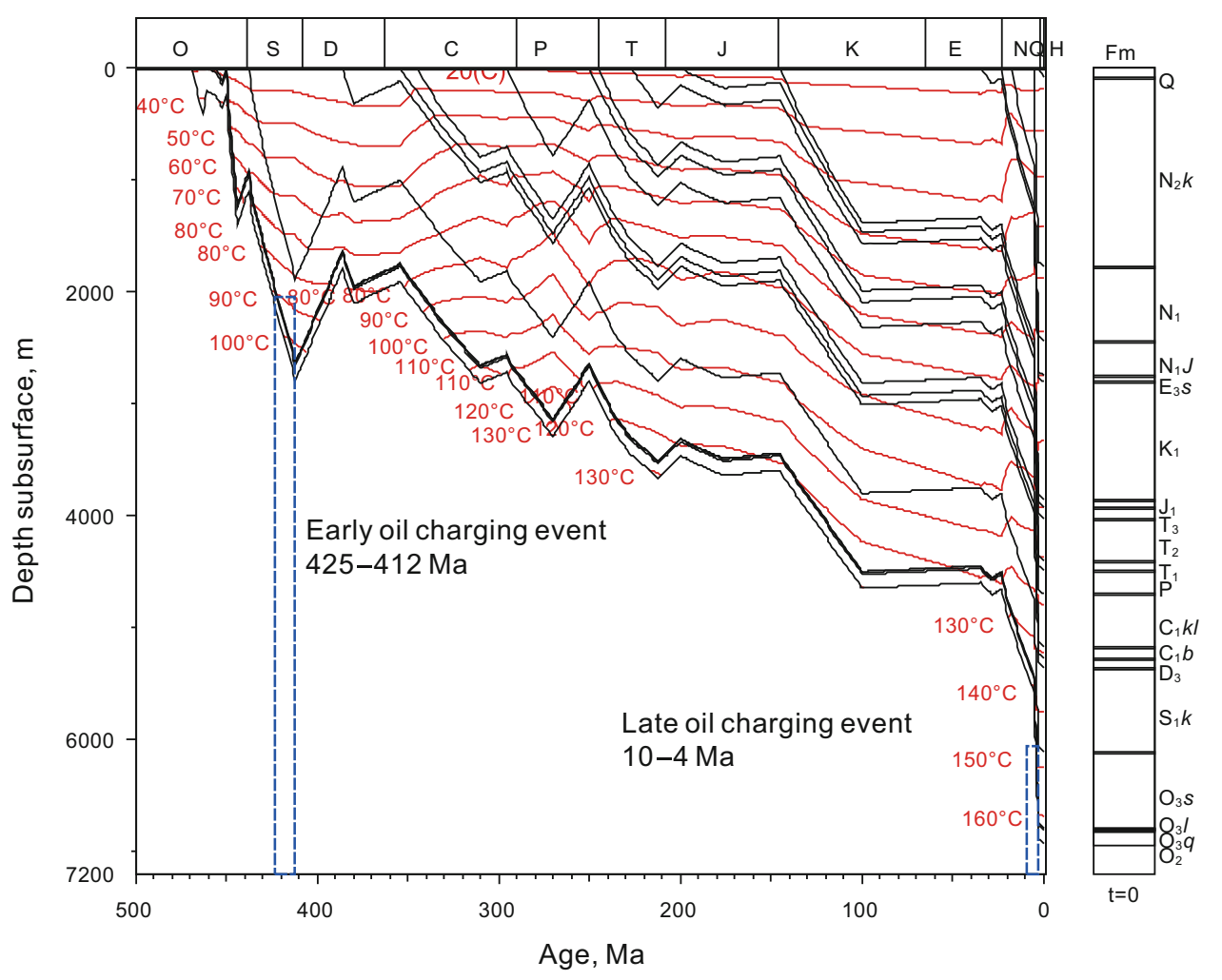

Fig. 7 Stratigraphic burial and geothermal history and oil charging and entrapment timing of the Ordovician carbonate reservoir in Well TP37 reconstructed by BasinMod 1D numerical modeling 


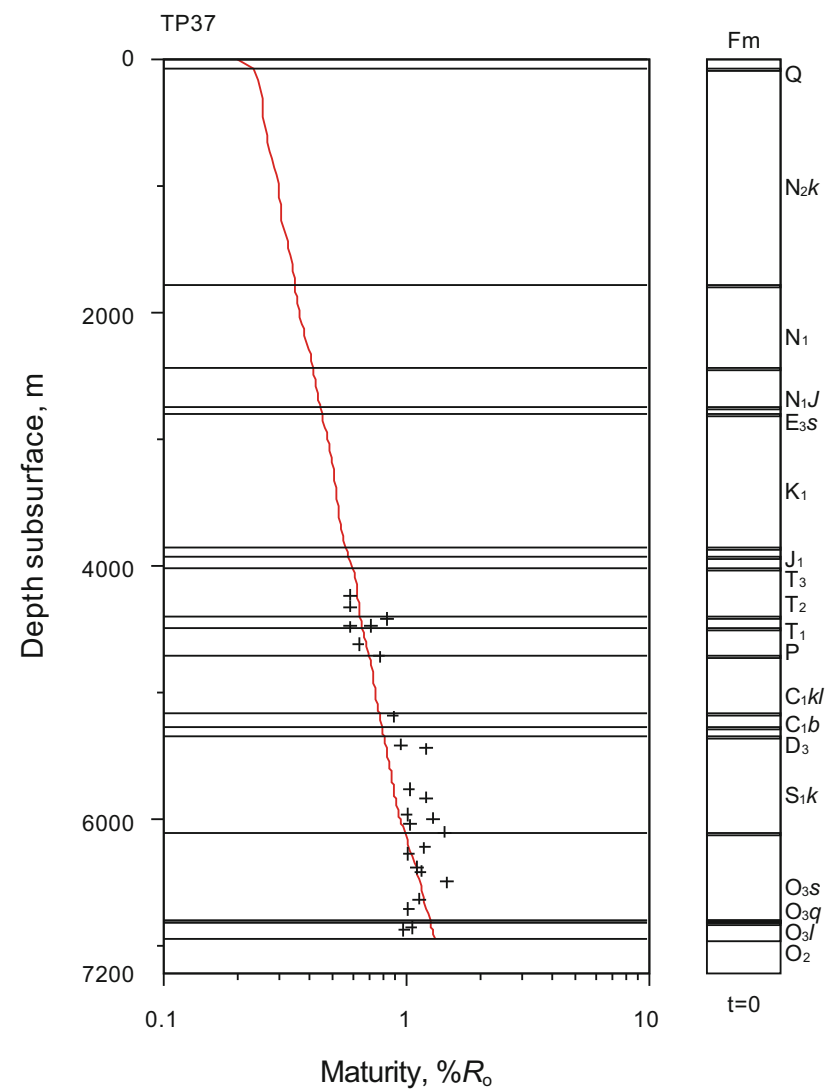

Fig. 8 Comparison between measured vitrinite reflectance $\left(\mathrm{V} R_{\mathrm{O}}\right)$ and calculated vitrinite reflectance $\left(\mathrm{V} R_{\mathrm{c}}\right)$ profiles in Well TP37

Figure 9 shows the isopleth map of the 4-/1-MDBT ratio of Ordovician oils from the Tuoputai region. The direction of decrease in the ratio indicates the oil migration orientation, and the projection trajectory of the isopleths indicates the preferential oil filling pathways. It is clear to see that there was one main oil filling point around Well TP329 at the southern side of the Tuoputai region, with a 4-/1MDBT ratio higher than 6.50. From there, two oil strings flowed northward. One migrated from south to northwest along Wells TP37, TP318, TP16, TP18 to Well TP217; the other migrated from south to northeast along Wells TP321X, TP315, TP208, TP227X to Well TP209CH.

Benzo[b]naphthothiophene (BNT) isomers, namely benzo $[b]$ naphtho[2,1- $d]$ thiophene, benzo $[b]$ naphtho[1,2$d]$ thiophene and benzo[b]naphtho[2,3-d]thiophene (abbr. [2,1]BNT, [1,2]BNT and [2,3]BNT, respectively), are structurally similar to benzo $[a]$ carbazole, benzo $[c]$ carbazole and benzo $[b]$ carbazole. The relative concentrations of $[2,1] \mathrm{BNT}$ and $[1,2] \mathrm{BNT}$ in reservoired oils are mainly affected by migration fractionation effects (Li et al. 2014a). The ratio of $[2,1] \mathrm{BNT} /([2,1] \mathrm{BNT}+[1,2] \mathrm{BNT})$ can be applied as a tracer for oil filling orientation and migration pathways ( $\mathrm{Li}$ et al. 2014a). The isopleth map of the $[2,1] \mathrm{BNT} /([2,1] \mathrm{BNT}+[1,2] \mathrm{BNT})$ ratio has been

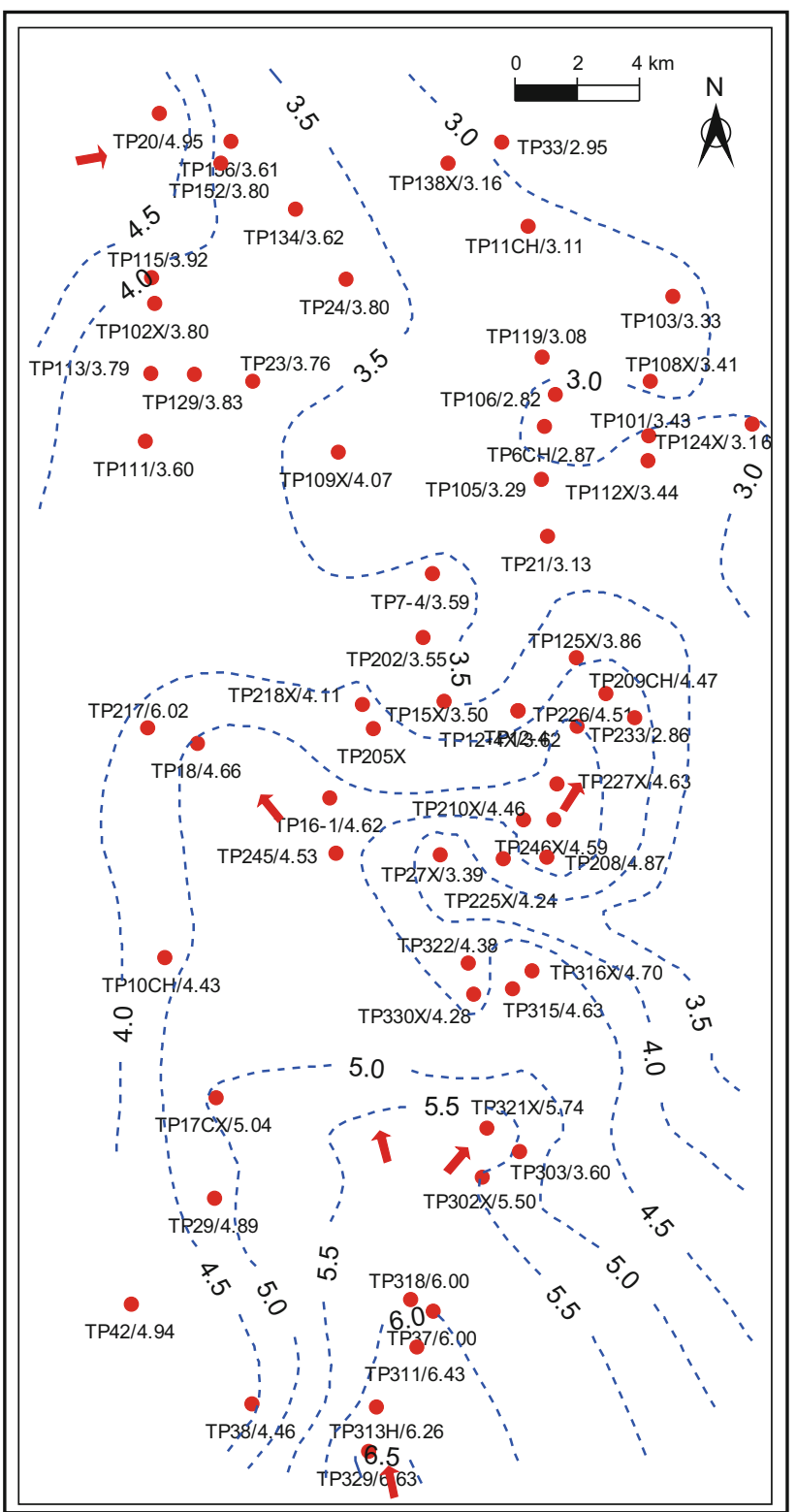

Fig. 9 Isopleth map of 4-/1-MDBT of the Ordovician oils showing the oil migration orientation and pathways in the Tuoputai region of the Tarim Basin, NW China. MDBT methyldibenzothiophene

successfully applied in the Ordovician carbonate reservoir of the Halahatang Oilfield in the Tabei Uplift (Fang et al. 2016). The isopleth map of the [2,1]BNT/ $([2,1] \mathrm{BNT}+[1,2] \mathrm{BNT})$ ratio for oils from the Tuoputai Oilfield is illustrated in Fig. 10. It shows that the ratios of $[2,1] \mathrm{BNT} /([2,1] \mathrm{BNT}+[1,2] \mathrm{BNT})$ of the Ordovician oils in the Tuoputai region decrease from south to north, which is approximately similar to that in the 4-/1-MDBT parameter. The main filling point indicated by this ratio is also around Well TP329.

Peng et al. (2010) and Yang et al. (2011) mapped the fracture-cavity units, the longitudinal distribution of 


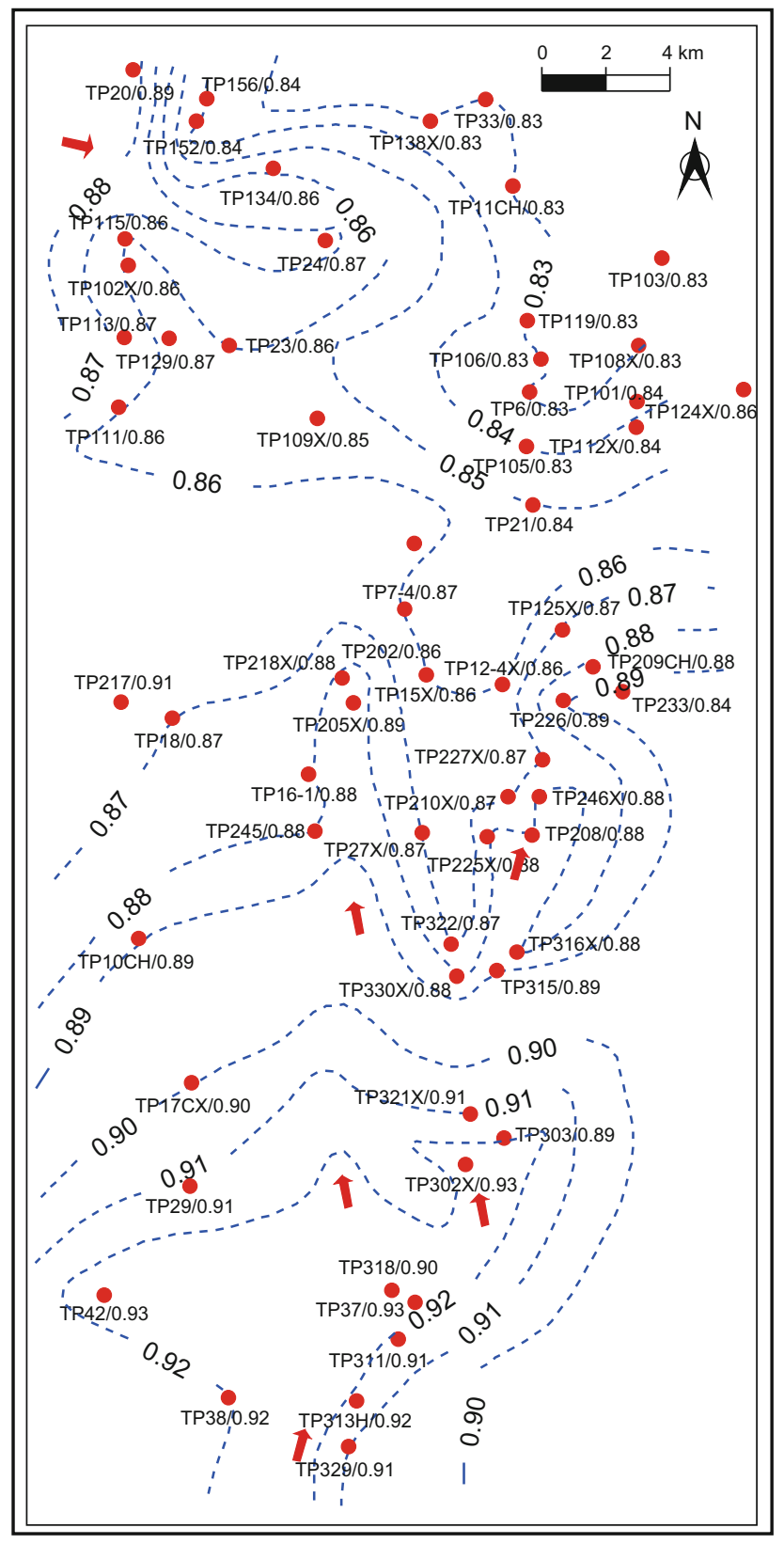

Fig. 10 Isopleth map of $[2,1] \mathrm{BNT} /([2,1] \mathrm{BNT}+[1,2] \mathrm{BNT})$ of the Ordovician oils showing the oil filling direction and pathways in the Tuoputai region of the Tarim Basin, NW China. [2,1]BNT/ $([2,1] \mathrm{BNT}+[1,2] \mathrm{BNT}):$ benzo[$[b]$ naphtho[2,1-d]thiophene/(benzo[ $b]$ naphtho $[2,1-d]$ thiophene + benzo $[b]$ naphtho[ $[1,2-d]$ thiophene)

fractures and cavities by means of drilling and logging data, seismic interpretation and production test. Clearly, the preferred oil migration pathways are consistent with the distribution of major fracture-cavity units.

\subsection{Implications for petroleum exploration}

On the whole, the tracing results of the oil filling stages demonstrate a general oil filling orientation from south to north in the Tuoputai region. The main oil filling point identified in this study is located around Well TP329. Therefore, the source kitchen/bed for the Ordovician reservoir of the Tuoputai region is predicted to be to the south side of the study area, most likely in the Shuntuoguole Uplift, which lies between the Awati and Manjiaer Depressions (Fig. 1). The location of the source kitchen/ bed is in agreement with the findings of previous studies (e.g., Wang et al. 2008; Chang et al. 2013b; Xiao et al. 2016; Fang et al. 2016).

During recent oil exploration efforts, a number of new boreholes in the south part of the Tuoputai region have delivered commercial light oil yields. A total of $8000 \times 10^{4} \mathrm{t}$ of controlled oil reserves have been discovered in the south part of the Tuoputai region. For example, the cumulative total of oil products from Well TP39, which is located in the southernmost of the Tuoputai region, reached over $12 \times 10^{4} \mathrm{t}$ by the end of 2014 . Therefore, the southern part of the Tuoputai region, along the oil charging pathways into the Tahe Oilfield, is likely to be the most prolific region for prospective development. The study of reservoir geochemistry therefore has real practical significance in petroleum exploration.

\section{Conclusions}

All Ordovician oils reservoired in the Tuoputai region possess similar molecular geochemical characteristics, such as the distribution characteristics of tricyclic terpanes, regular steranes and triaromatic steroids. They belong to a single oil family and evidently derived from the same source kitchen/bed.

Coupling the homogenization temperatures of fluid inclusions with stratigraphic burial and geothermal histories, reconstructed using $1 \mathrm{D}$ basin modeling, the episodes and timing of oil entrapment were determined. The results show that the Ordovician carbonate reservoir in the Tuoputai region has undergone two oil accumulation events. The early oil filling phase happened from 425 to $412 \mathrm{Ma}$ and the late one from 9 to $4 \mathrm{Ma}$, equivalent to the Middle to Late Silurian and the Miocene to Pliocene, respectively.

The oil migration and filling pathways were traced using isopleth maps of the 4-/1-MDBT and [2,1]BNT/ $([2,1] \mathrm{BNT}+[1,2] \mathrm{BNT})$ ratios. The oil filling orientation of the Ordovician oil reservoir in the Tuoputai region is generally from south to north. Therefore, the source kitchen/bed is predicted to lie to the south part of the 
Tuoputai region, most possibly in the Shuntuoguole Uplift. The prediction of preferred oil exploration targets has been proven to be of practical significance by its use in recent petroleum exploration discoveries in this region.

Acknowledgements This work was funded by the National Natural Science Foundation of China (Grant No. 41272158) and the Foundation of State Key Laboratory of Petroleum Resources and Prospecting, China University of Petroleum, Beijing (No. PRP/open1503). The authors are grateful for the assistance of Shengbao Shi, Lei Zhu and Daowei Wang in the GC-MS analysis and of Chengyu Yang in the microthermometry of fluid inclusions analyses. We would like to thank the Northwest Branch Company, SINOPEC, for providing samples and data and for permission to publish this work.

Open Access This article is distributed under the terms of the Creative Commons Attribution 4.0 International License (http://crea tivecommons.org/licenses/by/4.0/), which permits unrestricted use, distribution, and reproduction in any medium, provided you give appropriate credit to the original author(s) and the source, provide a link to the Creative Commons license, and indicate if changes were made.

\section{References}

Bressler DC, Norman JA, Fedorak PM, et al. Ring cleavage of sulfur heterocycles: how does it happen? Biodegradation. 1997;8:297-311. doi:10.1023/A:1008283207090.

Chang XC, Wang TG, Li QM, et al. Geochemistry and possible origin of petroleum in Palaeozoic reservoirs from Halahatang Depression. J Asian Earth Sci. 2013a;74:129-41. doi:10.1016/j.jseaes. 2013.03.024.

Chang XC, Wang TG, Li QM, et al. Charging of Ordovician reservoirs in the Halahatang Depression (Tarim Basin, NW China) determined by oil geochemistry. J Pet Geol. 2013b;36(4):383-98. doi:10.1111/jpg. 12562.

Chen HH, Li CQ, Zhang XM, et al. Application of fluid inclusion to determine episodes of petroleum reservoir forming. Earth Sci Front. 2003;10(1):190. doi:10.3321/j.issn:1005-2321.2003.01. 042 (in Chinese).

Ding Y, Yan YH, Gu Y, Li XM. The reservoir-formed history and mechanism of Tahe Oilfield in Tarim Basin. Xinjiang Pet Geol. 2001;22:478-9. doi:10.3969/j.issn.1001-3873.2001.06.008 (in Chinese).

Fang RH, Wang TG, Li MJ, et al. Dibenzothiophenes and benzo[b]naphthothiophenes: molecular markers for tracing oil filling pathways in the carbonate reservoir of the Tarim Basin, NW China. Org Geochem. 2016;91:68-80. doi:10.1016/j.orggeo chem.2015.11.004.

Gong S, George SC, Volk H, et al. Petroleum charge history in the Lunnan Low Uplift, Tarim Basin, China-evidence from oilbearing fluid inclusions. Org Geochem. 2007;38(8):1341-55. doi:10.1016/j.orggeochem.2007.02.014.

$\mathrm{Gu}$ Y. Forming mechanism of hydrocarbon pools in Tahe Oilfield of the Northern Tarim Basin. Pet Geol Exp. 2000;22:307-12. doi:10.3969/j.issn.1001-6112.2000.04.004 (in Chinese).

Hanson AD, Zhang SC, Moldowan JM, et al. Molecular organic geochemistry of the Tarim Basin, Northwest China. AAPG Bull. 2000;84(8):1109-28. doi:10.1306/A9673C52-1738-11D7$8645000102 \mathrm{C} 1865 \mathrm{D}$.

Huang JW. An approach to the application of biomarkers to the migration of crude oil in Tahe oil district of Tarim Basin. Pet
Geol Exp. 2003;25:573-6. doi:10.3969/j.issn.1001-6112.2003. z1.010 (in Chinese).

Jia CZ, Wei GQ. Structural characteristics and petroliferous features of Tarim Basin. Chin Sci Bull. 2002;47:1-11. doi:10.3321/j.issn: 0023-074X.2002.z1.001.

Jin ZJ, Zhu DY, Hu WX, et al. Mesogenetic dissolution of the middle Ordovician limestone in the Tahe oilfield of Tarim basin, NW China. Mar Pet Geol. 2008;26(6):767-77. doi:10.1016/j.marpet geo.2008.08.005.

Kang YZ, Kang ZH. Tectonic evolution and oil and gas of Tarim basin. J Southeast Asian Earth Sci. 1996;13(3-5):317-25. doi:10.1016/0743-9547(96)00038-4.

Li HB, Wang TG, Li MJ. Tracing study on oil-gas filling pathways of Yakela gas condensate field in Tabei Uplift. Acta Pet Sin. 2013a;34(2):119-224. doi:10.7623/syxb201302002 (in Chinese).

Li MJ, Wang TG, Liu J, et al. Total alkyl dibenzothiophenes content tracing the filling pathway of condensate reservoir in the Fushan Depression, South China Sea. Sci China Ser D Earth Sci. 2008;51(S2):138-45. doi:10.1007/s11430-008-6025-6.

Li MJ, Wang TG, Chen JF, et al. Paleo-heat flow evolution of the Tabei Uplift in Tarim Basin, northwest China. J Asian Earth Sci. 2010a;37(1):52-66. doi:10.1016/j.jseaes.2009.07.007.

Li MJ, Wang TG, Lillis PG, et al. The significance of 24-norcholestanes, triaromatic steroids and dinosteroids in oils and Cambrian-Ordovician source rocks from the cratonic region of the Tarim Basin, NW China. Appl Geochem. 2012;27(8):1643-54. doi:10.1016/j.apgeochem.2012.03.006.

Li MJ, Wang TG, Zhong NN, et al. Ternary diagram of fluorenes, dibenzothiophenes and dibenzofurans: indicating depositional environment of crude oil source rocks. Energy Explor Exploit. 2013b;31(4):569-88. doi:10.1260/0144-5987.31.4.569.

Li MJ, Wang TG, Shi SB, et al. Benzo[b]naphthothiophenes and alkyl dibenzothiophenes: molecular tracers for oil migration distances. Mar Pet Geol. 2014a;57:403-17. doi:10.1016/j.marpetgeo.2014. 06.012 .

Li MJ, Wang TG, Shi SB, et al. Oil maturity assessment using maturity indicators based on methylated dibenzothiophenes. Pet Sci. 2014b;11(2):234-46. doi:10.1007/s12182-014-0336-3.

Li SM, Pang XQ, Jin ZJ, et al. Petroleum source in the Tazhong Uplift, Tarim Basin: new insights from geochemical and fluid inclusion data. Org Geochem. 2010b;41(6):531-53. doi:10.1016/ j.orggeochem.2010.02.018.

Li SM, Amrani A, Pang XQ, et al. Origin and quantitative source assessment of deep oils in the Tazhong Uplift, Tarim Basin. Org Geochem. 2015;78:1-22. doi:10.1016/j.orggeochem.2014.10. 004.

Li YZ, Xu CH. Significance and discovery history of Tahe Oilfield of the Tarim Basin. Pet Geol Exp. 2004;26:180-6. doi:10.3969/j. issn.1001-6112.2004.02.010 (in Chinese).

Liu DH, Xiao XM, Mi JK, et al. Determination of trapping pressure and temperature of petroleum inclusions using PVT simulation software-a case study of Lower Ordovician carbonates from the Lunnan Low Uplift, Tarim Basin. Mar Pet Geol. 2003;20(1):29-43. doi:10.1016/S0264-8172(03)00047-3.

Liu DH, Gong S, Liu DY, et al. Investigation on the phases of organic inclusion from Gourong-Huangqiao region, Jiangsu Province, and its trapped temperature \& pressure calculated by PVTsim modeling. Acta Pet Sin. 2005;21(5):1435-48. doi:10.3321/j.issn: 1000-0569.2005.05.015 (in Chinese).

Lu YH, Xiao ZY, Gu QY, Zhang QC. Geochemical characteristics and accumulation of marine oil and gas around Halahatang depression, Tarim Basin, China. Sci China Ser D Earth Sci. 2008;51:195-206. doi:10.1007/s11430-008-5006-0. 
Ma AL, Zhang SC, Zhang DJ, et al. Organic geochemistry of TD-2 well in Tarim Basin. Xinjiang Pet Geol. 2005;26:148-51. doi:10. 3969/j.issn.1001-3873.2005.02.008.

Mazeas L, Budzinski H, Raymond N. Absence of stable carbon isotope fractionation of saturated and polycyclic aromatic hydrocarbons during aerobic bacterial biodegradation. Org Geochem. 2002;33(11):1259-72. doi:10.1016/S01466380(02)00136-5.

Mi JK, Zhang SC, Chen JP, et al. The distribution of the oil derived from Cambrian source rocks in Lunnan area, the Tarim Basin, China. Chin Sci Bull. 2007;52(A01):133-40. doi:10.1007/ s11434-007-6004-X.

Ni ZY, Wang TG, Li MJ, et al. An examination of the fluid inclusions of the well RP3-1 at the Halahatang Sag in Tarim Basin, northwest China: implications for hydrocarbon charging time and fluid evolution. J Pet Sci Eng. 2016;146:326-39. doi:10. 1016/j.petrol.2016.04.038.

Peng ST, He ZL, Ding Y, et al. Characteristics and major controlling factors of carbonates reservoir in the middle Ordovician Yijianfang Formation, Tuofutai area, Tahe Oilfield. Pet Geol Exp. 2010;32:108-13. doi:10.3969/j.issn.1001-6112.2010.02. 002 (in Chinese).

Peters KE, Walters CC, Moldowan JM. The biomarker guide. New York: Cambridge University Press; 2005.

Shi SB, Chen JF, Chen L, et al. Anaerobic biodegradation of dibenzothiophene and its homologues in crude oils. In: 27th international meeting on organic geochemistry, Prague, Czech Republic. 13-18 Sept 2015

Shi WJ, Jiang H, Xi BB. Application of the PVTX Simulation of reservoir fluid inclusions to estimate petroleum charge stages: a case study in the Tuoputai area of Tarim Basin. Geol J China Univ. 2012;18:125-32. doi:10.3969/j.issn.1006-7493.2012.01. 011.

Song DF, Wang TG, Li MJ. Geochemistry and possible origin of the hydrocarbons from wells Zhongshen1 and Zhongshen1C, Tazhong Uplift. Sci China Ser D Earth Sci. 2016;46:107-17. doi:10.1007/s11430-015-5226-z.

Wang TG, He FQ, Li MJ, et al. Alkyldibenzothiophenes: molecular tracers for filling pathway in oil reservoirs. Chin Sci Bull. 2004a;49(22):2399-404. doi:10.1007/BF03183429.

Wang TG, Li SM, Zhang SC. Oil migration in the Lunnan region, Tarim Basin, China based on the pyrrolic nitrogen compound distribution. J Pet Sci Eng. 2004b;41(s1-3):123-34. doi:10.1016/ S0920-4105(03)00148-7.
Wang TG, He FQ, Wang CJ, et al. Oil filling history of the Ordovician oil reservoir in the major part of the Tahe Oilfield, Tarim Basin, NW China. Org Geochem. 2008;39(11):1637-46. doi:10.1016/j.orggeochem.2008.05.006.

Xiao ZY, Li MJ, Huang SY, et al. Source, oil charging history and filling pathways of the Ordovician carbonate reservoir in the Halahatang Oilfield, Tarim Basin, NW China. Mar Pet Geol. 2016;73:59-71. doi:10.1016/j.marpetgeo.2016.02.026.

Yang YC, Yang YD, Wang C. Characteristics and major controlling factors of Ordovician carbonates oil and gas reservoir in Tuofutai area, Tahe Oilfield. Xinjiang Oil Gas. 2011;7(1):6-11. doi:10.3969/j.issn.1673-2677.2011.01.002 (in Chinese).

Yu S, Pan CC, Wang JJ, et al. Molecular correlation of crude oils and oil components from reservoir rocks in the Tazhong and Tabei uplifts of the Tarim Basin, China. Org Geochem. 2011;42(10):1241-62. doi:10.1016/j.orggeochem.2011.08.002.

Zhang K. The discovery of Tahe Oilfield and its geologic implication. Oil Gas Geol. 1999;20:120-4 (in Chinese).

Zhang SC, Hanson AD, Moldowan JM, et al. Paleozoic oil-source rock correlations in the Tarim basin, NW China. Org Geochem. 2000;31(4):273-86. doi:10.1016/S0146-6380(00)00003-6.

Zhang SC, Huang HP. Geochemistry of Palaeozoic marine petroleum from the Tarim Basin, NW China: part 1. Oil family classification. Org Geochem. 2005;36(8):1204-14. doi:10.1016/j.org geochem.2005.01.013.

Zhang SC, Moldowan JM, Li M, et al. The abnormal distribution of the molecular fossils in the pre-Cambrian and Cambrian: its biological significance. Sci China Ser D- Earth Sci. 2002;45:193-200. doi:10.1360/02yd9021.

Zhou YQ, Li YZ, Hou HB. Practice and knowledge of geological exploration in the Tahe Oilfield. Pet Geol Exp. 2001;23:363-7. doi:10.3969/j.issn.1001-6112.2001.04.001 (in Chinese).

Zhu GY, Yang HJ, Zhu YF, et al. Study on petroleum geological characteristics and accumulation of carbonate reservoirs in Hanilcatam area, Tarim Basin. Acta Pet Sin. 2011;27(3):827-44 (in Chinese).

Zhu GY, Zhang SC, Su J, et al. Alteration and multi-stage accumulation of oil and gas in the Ordovician of the Tabei Uplift, Tarim Basin, NW China: implications for genetic origin of the diverse hydrocarbons. Mar Pet Geol. 2013;46:234-50. doi:10.1016/j.marpetgeo.2013.06.007. 